\title{
383. Einfluß der intermittierenden Kompression und von körperlichem Training auf verschiedene Parameter der Blutgerinnung und Fibrinolyse
}

\author{
S. Haas, A. Stemberger, H. Altenkämper ${ }^{1}$, K. Geißdörfer, R. Hipp. W. Haller, H. Weithmann \\ und G. Blümel
}

Institut für Experimentelle Chirurgie (Dir.: Prof. Dr. G. Blümel) der Technischen Universität München, Ismaninger Straße 22, D-8000 München 80, und ${ }^{1}$ Venenambulanz Dr. Altenkämper, Plettenberg - Mit Unterstützung des Arbeitskreises für Transfusionsmedizin, Onkologie und Hämostaseologie e.V. München

\section{The Effect of Intermittent High-Pressure Compression and Exercise on Various Parameters of Blood Coagulation and Fibrinolysis}

\begin{abstract}
Summary. In 30 patients with varicosis intermittent high-pressure compression of the leg was applied before a stripping operation and the fibrinolytic activity of intraoperatively obtained vein segments was studied histochemically. In comparison with 10 non-treated patients the fibrinolytic activity of the vessel wall was markedly increased. The systemic enhancement of fibrinolysis was only seen when the blood was drawn from the treated extremity. In addition, after active exercise, i.e. moutaineering and cross-country skiing under competition conditions, a significant activation of fibrinolysis and coagulation was seen in the plasma of the volunteers.
\end{abstract}

Key words: Intermittent high-pressure compression - Exercise - Fibrinolysis - Blood coagulation.

Zusammenfassung. Bei 30 Varikosis-Patienten wurde vor einem Stripping eine intermittierende Kompression (Hydroven S) des Beines angelegt und anschließend die fibrinolytische Aktivität von intraoperativ entnommenen Venensegmenten histochemisch untersucht. Im Vergleich zu 10 unbehandelten Patienten konnte hierdurch die fibrinolytische Aktivität der Venenwand deutlich erhöht werden. Eine systemische Fibrinolyseaktivierung war nur in dem an der zuvor komprimierten Extremität entnommenen Blut nachweisbar. Ebenso führt eine aktive Bewegung wie z. B. Bergsteigen und Skilanglauf unter Wettkampfbedingungen zu einer deutlichen im Plasma nachweisbaren Aktivierung der Fibrinolyse. Darüberhinaus konnte bei diesen freiwilligen Probanden auch eine Aktivierung der Blutgerinnung nachgewiesen werden.

Schluisselwörter: Intermittierende Kompression - Körperliches Training - Fibrinolyse - Blutgerinnung.

\section{Der kontralaterale epigastrische Lappen - Eine neue Technik der Brustrekonstruktion mit Eigengewebe}

\author{
H. Bohmert und H. Büchels \\ Abteilung Plastische Chirurgie der Chirurgischen Klinik und Poliklinik, Klinikum Großhadern, \\ Marchioninistraße 15, D-8000 München 70
}

\section{The Contralateral Thoracoepigastric Flap - A New Technique for Breast Reconstruction Using Patient's Own Tissue}

Summary. Based on our anatomical studies of the blood supply of the thoracoepigastric flap, we have developed a new method of breast reconstruction. This flap is used from the contralateral side, based on the rectus abdominis muscle and including the superior epigastric artery. This flap is transferred to the mastectomized side. The skin and subcutaneous tissue below the mastectomy scar are used for the reconstruction, following deepithelisation and upper abdominal advancement of the soft tissue.

Key words: Breast reconstruction - Myocutaneous flap.

Zusammenfassung. Basierend auf den anatomischen Studien des Autors über die Gefäßversorgung des thoracoepigastrischen Lappens entstand die Idee, diesen Lappen von der Gegenseite zum Ausgleich des Mastektomiedefektes einzuschwenken. Der Lappen wird mit dem medialen Anteil des Rectusmuskels und den darin befindlichen Gefäßen verlagert. Die Gefäßversorgung erfolgt über die A. epigastrica superior und ihren lateralen Ast, der als axial verlaufendes Gefäß die Blutversorgung sichert. Der Lappen wird um $180^{\circ}$ in den Mastektomiedefekt eingesetzt. Der Gewebeüberschuß von der ipsilateralen Seite wird zum Volumenaufbau der zu bildenden Brust verwendet.

Schlüsselwörter: Brustrekonstruktion - Hautmuskellappen. 